American Journal of Applied Sciences 9 (3): 365-367, 2012

ISSN 1546-9239

(C) 2012 Science Publications

\title{
The Effect of R/X Ratio of the Short Transmission Line on Transient Stability
}

\author{
Prechanon Kumkratug \\ Division of Electrical Engineering, Faculty of Engineering at Si Racha, \\ Kasetsart University, 199 M.6, Tungsukhla, Si Racha, Chonburi, 20230, Thailand
}

\begin{abstract}
Problem statement: The exact short transmission line model consists of the resistance and reactance. Most of previous researches study the transient stability of single machine infinite bus with neglecting the resistance of the line. Thus the simulation results may not close to the practical system. With the consideration with the actual short line model, it causes difficulty of deriving the mathematical model. Approach: This study investigates the transient stability of power system with consideration of the exact short transmission line model. The concept of two-port network is applied in this study. The generator, transformer and short transmission line are represented by a two-port. With the combination principles of the series and shunt connection, the mathematical model is achieved in a much simpler way. The proposed method is tested on the sample system and compared on various cases. Results: The first swing of rotor angle curve of the faulted system without the resistance is obviously higher than that of with the resistance whereas the second swing of the faulted system, without the resistance, is slightly less than that of with the resistance. The critical clearing time of the system with the resistance is better than that of with resistance. Conclusion: It was found in this study that the resistance of the transmission line should be included for investigating the transient stability of the power system. The resistance of the line provides the better results of the critical clearing time of the system but it provides the negative effect on damping improvement.
\end{abstract}

Key words: Power system stability, transient stability, critical clearing time, resistance, transmission line, two-port network, the transmission line, resistance gets, existing transmission

\section{INTRODUCTION}

Nowadays, the demand of electricity has dramatically increased and a modern power system becomes a complex network of transmission lines interconnecting the generating stations to the major loads points in the overall power system in order to support the high demand of consumers. It is becoming increasingly important to fully utilize the existing transmission system assets due to environmental legislation, rights-of-way issues and cost of construction and deregulation policies that introduced in recent years. A number of Flexible AC Transmission System (FACTS) controllers, based on the rapid development of power electronics technology, have been proposed for better utilization of the existing transmission systems (Kumkratug, 2010; Osuwa and Igwiro, 2010; Magaji and Mustafa, 2009; ZarateMinano et al., 2010).

The evaluation of Critical Clearing Time (CCT) of power system is one of the most important research areas for power engineers because it indicates the robustness of the faulted power system. The dynamic behavior of synchronous generator plays very important role to determine the CCT of power system.

The transmission line is one of the most important parts in power system components. The transmission line is generally divided into three major categories; short, medium and long model whose distance are about $80 \mathrm{~km}$, above $80-250 \mathrm{~km}$ and above $250 \mathrm{~km}$, respectively. Many previous researches used simple transmission line model by neglecting its resistance or capacitance. To fully utilization the existing the transmission, the exact transmission line is needed to studied.

This study will investigate the critical clearing time of the system with consideration the resistance of the short transmission line. The concept of two-port network is applied to simplify the mathematical model of the power system. The proposed method is tested on sample system and compared on various cases. 
Am. J. Applied Sci., 9 (3): 365-367, 2012

\section{MATERIALS AND METHODS}

Mathematical model: Fig. 1a shows the single line diagram of power system consisting of a generator, a transformer and four short transmission lines. Fig. 1b shows the equivalent of Fig. 1a. The generator is represented by a synchronous voltage in quadrature axis $\left(\mathrm{E}_{\mathrm{q}}^{\prime}\right)$ behind direct transient reactance $\left(\mathrm{X}_{\mathrm{d}}{ }^{\prime}\right)$. The $\mathrm{V}_{\mathrm{b}}$ is the voltage at infinite bus. The exact short transmission line model is represented by the impedance $\left(\mathrm{Z}_{\mathrm{L}}\right)$ which consists of a resistance $\left(\mathrm{R}_{\mathrm{L}}\right)$ and reactance $\left(\mathrm{X}_{\mathrm{L}}\right)$. This study applies the concepts of the two-port network to simplify the equivalent in Fig. 1b. Each component of power system can be represented the matrix of two-port networks (A, B, $\mathrm{C}$ and D) as shown in Fig. 1c and given by Eq. 1-6:

$$
\begin{aligned}
& \mathrm{A}_{1}=\mathrm{A}_{2}=\mathrm{A}_{3}=\mathrm{A}_{4}=\mathrm{A}_{5}=\mathrm{A}_{6}=1 \\
& \mathrm{~B}_{1}=\mathrm{j} \mathrm{X}_{\mathrm{d}}^{\prime} \\
& \mathrm{B}_{2}=\mathrm{j} \mathrm{X}_{\mathrm{t}}^{\prime} \\
& \mathrm{B}_{3}=\mathrm{B}_{4}=\mathrm{B}_{5}=\mathrm{B}_{6}=\mathrm{j} \mathrm{Z}_{\mathrm{L}} \\
& \mathrm{C}_{1}=\mathrm{C}_{2}=\mathrm{C}_{3}=\mathrm{C}_{4}=\mathrm{C}_{5}=\mathrm{C}_{6}=0 \\
& \mathrm{D}_{1}=\mathrm{D}_{2}=\mathrm{D}_{3}=\mathrm{D}_{4}=\mathrm{D}_{5}=\mathrm{D}_{6}=1
\end{aligned}
$$

It can be seen from the Fig. 1c that some ports are in series and in shunt connection. For example, a port 1 and port 2 are in series connection whereas port 3 and port 4 are in shunt connection. Thus with the series combination of port 1 and port 2, a new port is given by Eq. 7-10:

$$
\begin{aligned}
& \mathrm{A}_{\mathrm{s}}=\mathrm{A}_{1} \mathrm{~A}_{2}+\mathrm{B}_{1} \mathrm{C}_{2} \\
& \mathrm{~B}_{\mathrm{s}}=\mathrm{A}_{1} \mathrm{~B}_{2}+\mathrm{B}_{1} \mathrm{D}_{2} \\
& \mathrm{C}_{\mathrm{s}}=\mathrm{A}_{2} \mathrm{C}_{1}+\mathrm{C}_{2} \mathrm{D}_{1} \\
& \mathrm{D}_{\mathrm{s}}=\mathrm{B}_{2} \mathrm{C}_{1}+\mathrm{D}_{1} \mathrm{D}_{2}
\end{aligned}
$$

Similarly, with the shunt combination of port 3 and port 4, a new port is given by Eq. 11-15:

$$
\begin{aligned}
& \mathrm{A}_{\mathrm{sh}}=\left(\mathrm{A}_{3} \mathrm{~B}_{4}+\mathrm{A}_{4} \mathrm{~B}_{3}\right) /\left(\mathrm{B}_{3}+\mathrm{B}_{4}\right) \\
& \mathrm{B}_{\mathrm{sh}}=\mathrm{B}_{3} \mathrm{~B}_{4} /\left(\mathrm{B}_{3}+\mathrm{B}_{4}\right) \\
& \mathrm{C}_{\mathrm{sh}}=\mathrm{C}_{1}+\mathrm{C}_{2}+\left(\mathrm{A}_{1}-\mathrm{A}_{2}\right)\left(\mathrm{D}_{2}-\mathrm{D}_{1}\right) /\left(\mathrm{B}_{1}+\mathrm{B}_{2}\right) \\
& \mathrm{D}_{\mathrm{sh}}=\left(\mathrm{B}_{4} \mathrm{D}_{3}+\mathrm{B}_{3} \mathrm{D}_{4}\right) /\left(\mathrm{B}_{3}+\mathrm{B}_{4}\right)
\end{aligned}
$$

With the above concepts, the net two-port network diagram is shown in Fig. 1d. Here $A_{\text {eq }}, B_{\text {eq }}, C_{\text {eq }}$ and $D_{\text {eq }}$ are the element in net matrix of net two-port networks.

The output electrical power of synchronous machine $\left(\mathrm{P}_{\mathrm{e}}\right)$ is given by:

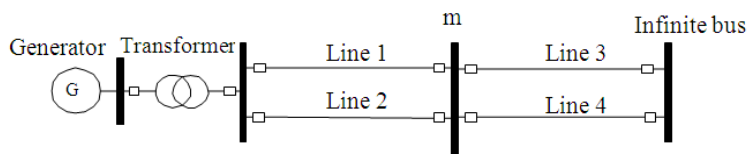

(a)

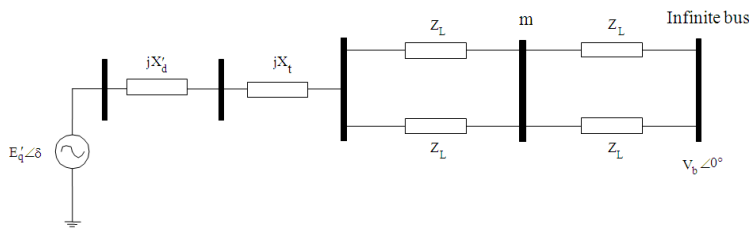

(b)

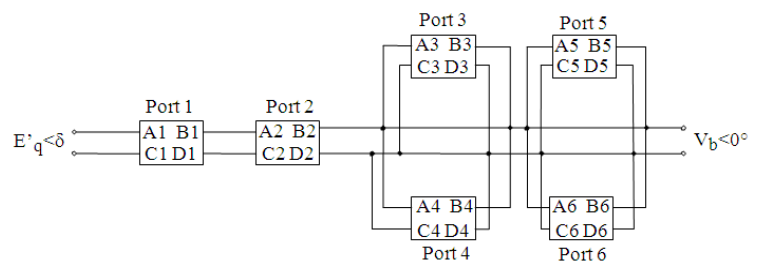

(c)

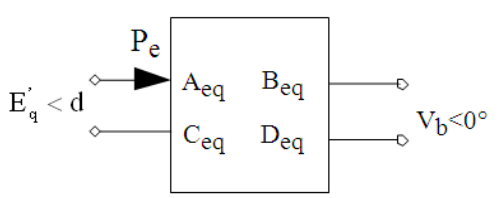

(d)

Fig. 1: Single machine infinite bus system with consideration of the exact short line model (a) schematic diagram (b) equivalent circuit (c) two port networks diagram (d) the net two-port network

$P_{e}=\frac{A_{e q}\left(E_{q}^{\prime}\right)^{2}}{B_{\text {eq }}} \cos \left(\theta_{\text {Beq }}-\theta_{\text {Aeq }}\right)-\frac{V_{b} E_{q}^{\prime}}{B_{\text {eq }}} \cos \left(\theta_{\text {Beq }}+\delta\right)$

Here:

$$
\mathrm{A}_{\text {eq }}=\mathrm{A}_{\text {eq }} \angle \theta_{\text {Aeq }} \mathrm{B}_{\text {eq }}=\mathrm{B}_{\text {eq }} \angle \theta_{\mathrm{Beq}}
$$

The dynamic equation for evaluating critical clearing tine of the system in Fig. 1a is given by Eq. 16 and 17:

$\dot{\delta}=\omega$

$\dot{\omega}=\frac{1}{\mathrm{M}}\left[\mathrm{P}_{\mathrm{m}}-\mathrm{P}_{\mathrm{e}}\right]$

Here, $\delta, \omega$ and $\mathrm{P}_{\mathrm{m}}$ are the rotor angle, speed, mechanical input power and moment of inertia, respectively of synchronous machine.

\section{RESULTS}

Consider the diagram of sample system is shown in 366 
$\mathrm{H}=5, \mathrm{X}_{\mathrm{t}}=0.1 \mathrm{pu}, \mathrm{X}_{\mathrm{d}}^{\prime}=0.20 \mathrm{pu}, \mathrm{X}_{\mathrm{L} 1}=0.5 \mathrm{pu}, \mathrm{X}_{\mathrm{L} 2}=$ $0.5 \mathrm{pu}, \mathrm{X}_{\mathrm{L} 3}=0.5 \mathrm{pu}, \mathrm{X}_{\mathrm{L} 4}=0.5 \mathrm{pu}, \mathrm{E}_{\mathrm{q}}=1.22<31.64 \mathrm{pu}$, $\mathrm{V}_{\mathrm{b}}=1 \mathrm{pu}$

It is considered that three phase fault appears at line 2 near bus $m$ and the fault is cleared by opening circuit breakers at the end of the line. Figure 2 shows the rotor angle of the system with clearing time $\left(\mathrm{t}_{\mathrm{cl}}\right)$ for 170 msec. The break line represents the rotor angle of the system without consideration of line resistance $(\mathrm{R} / \mathrm{X}=$ $0)$ whereas the dash line represents the rotor angle of the system with $\mathrm{R} / \mathrm{X}=5 \%$.

Figure 3 shows the rotor angle of the system with $\mathrm{R} / \mathrm{X}=0$ and $\mathrm{R} / \mathrm{X}=5 \%$ for $\mathrm{t}_{\mathrm{cl}}=191 \mathrm{~m} \mathrm{sec}$. Table 1 summarizes the critical clearing time $\left(\mathrm{t}_{\mathrm{cr}}\right)$ of the system with various $\mathrm{R} / \mathrm{X}$.

\begin{tabular}{llll}
\multicolumn{4}{l}{ Table 1: The critical clear time of the system with various values of R/X } \\
\hline Case & $\mathrm{R} / \mathrm{X}(\%)$ & $\mathrm{P}_{\mathrm{m}}(\mathrm{pu})$ & $\mathrm{t}_{\mathrm{cr}}(\mathrm{m} \mathrm{sec})$ \\
\hline 1 & 0 & 0.800 & $190-191$ \\
2 & 5 & 0.817 & $197-198$ \\
3 & 10 & 0.832 & $203-204$ \\
4 & 15 & 0.845 & $210-211$ \\
5 & 20 & 0.857 & $216-217$ \\
6 & 25 & 0.867 & $222-223$ \\
7 & 30 & 0.875 & $228-229$ \\
8 & 35 & 0.881 & $234-235$ \\
9 & 40 & 0.885 & $240-241$ \\
10 & 45 & 0.888 & $245-246$ \\
11 & 50 & 0.889 & $251-252$ \\
\hline
\end{tabular}

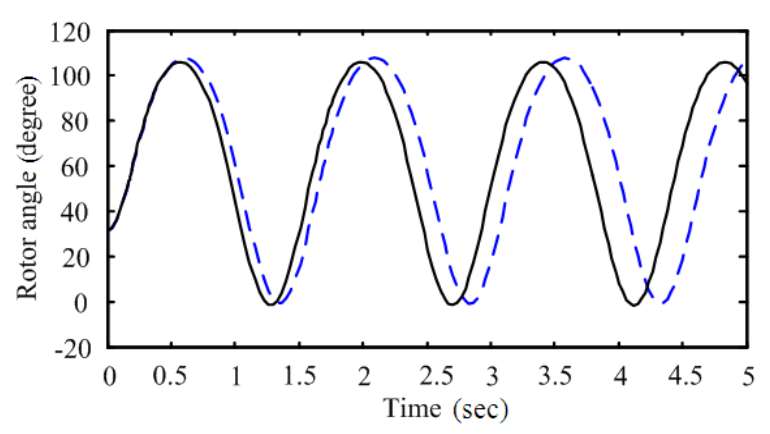

Fig. 2: Swing curve of the system with $R / X=0$ and $\mathrm{R} / \mathrm{X}=5 \%$ for $\mathrm{t}_{\mathrm{cl}}=170 \mathrm{~m} \mathrm{sec}$

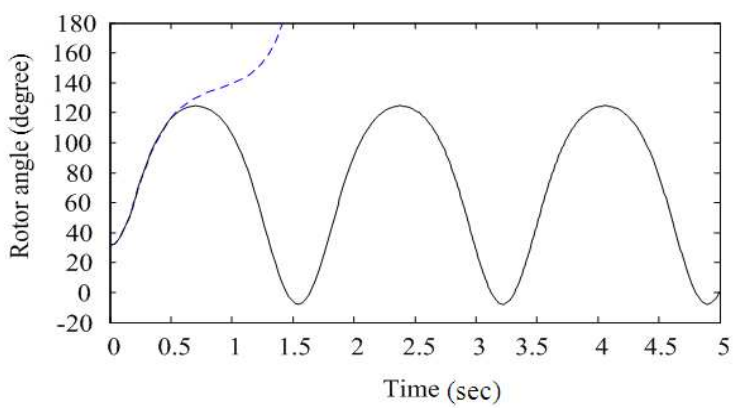

Fig. 3: Swing curve of the system with $R / X=0$ and $\mathrm{R} / \mathrm{X}=5 \%$ for $\mathrm{t}_{\mathrm{cl}}=191 \mathrm{~m} \mathrm{sec}$

\section{DISCUSSION}

It can be seen from the Fig. 2 that resistance of the line provides the improvement of the first swing stability but not for the sec swing. With the $\mathrm{R} / \mathrm{X}=0$, the maximum and the minimum rotor angle are 107.80 and$0.63^{\circ}$, respectively whereas with the $\mathrm{R} / \mathrm{X}=5 \%$, the maximum and the minimum rotor angle are 105.95 and$1.36^{\circ}$, respectively. With $\mathrm{R} / \mathrm{X}=0$, the critical clearing time of the system is $190-191 \mathrm{~m} \mathrm{sec}$ whereas with $\mathrm{R} / \mathrm{X}$ $=5 \%$ the critical clearing is increased to around 197$198 \mathrm{~m} \mathrm{sec}$. With $\mathrm{t}_{\mathrm{cl}}=191 \mathrm{~m} \mathrm{sec}$, the system without consideration of line resistance can be considered as unstable but for with line resistance is stable as shown in Fig. 3. It can observe from the Table 1 that the critical clearing time of the system is increased as the percent of $\mathrm{R} / \mathrm{X}$ gets increase.

\section{CONCLUSION}

This study investigated the critical clearing time of the system with consideration the resistance of the transmission line. The concept of two-port network is applied to simplify mathematical model of the power system. The reactance of generator, transformer and exact short line model can be represented by a net twoport network.

It was found from the simulation results that the resistance of the line provides the improvement of the first swing but not for the second swing. The resistance of the line affect on the critical clearing time of the single machine infinite bus system. The critical clearing time is increased as the resistance gets increase.

\section{REFERENCES}

Kumkratug, P., 2010. Application of interline power flow controller to increase transient stability of power system. J. Comput. Sci., 6: 1490-1493. DOI: 10.3844/jcssp.2010.1490.1493

Magaji, M. and M.W. Mustafa, 2009. Optimal Thyristor control series capacitor neuro-controller for damping oscillations. J. Comput. Sci., 5: 980987. DOI: $10.3844 /$ jcssp.2009.980.987

Osuwa, J.C. and E.C. Igwiro, 2010. Uninterruptible power supply using solar rechargeable battery. Phys. Int., 1: 77-82. DOI: 10.3844/pisp.2010.77.82

Zarate-Minano, R., T.V. Custsem, F., Milano and A.J. Conejo, 2010. Securing transient stability using time-domain simulations within an optimal power flow. IEEE Trans. Power Syst., 25: 243-253. DOI: 10.1109/TPWRS.2009.2030369 